\title{
Effect of Stress Tolerant Plant Growth Promoting Rhizobacteria on Growth of Blackgram under Stress Condition
}

\author{
M. Eswara Raghava Kumari*, A. Vijaya Gopal and R. Lakshmipathy \\ Department of Agricultural Microbiology, APGC, Lam, Guntur-522034, \\ Andhra Pradesh, India \\ *Corresponding author
}

\begin{abstract}
A B S T R A C T
Keywords

PGPR, Rhizobium.

Pseudomonas, Potassium

releasing bacteria $(\mathrm{KRB})$,

Zinc solubilizing bacteria

(ZSB), Blackgram, 1-

Aminocyclopropane-1

carboxylate (ACC)

deaminase,

Exopolysaccharide (EPS)

Article Info

Accepted:

12 December 2017

Available Online:

10 January 2018

Stress tolerant Plant growth-promoting rhizobacteria (PGPR) are the rhizosphere bacteria that can enhance plant growth under stress condition. In our present study, 32 stress tolerant PGPR strains (8 Rhizobium. 8 Pseudomonas, 8 KRB, 8ZSB) were isolated from the rhizosphere soils of blackgram crop and screened for their ACC deaminase and Exopolysaccharide (EPS) production. Out of 32 isolates four isolates (1 Rhizobium. 1 Pseudomonas, $1 \mathrm{KRB}, 1 \mathrm{ZSB}$ ) were selected on the basis of their ACC deaminase activity and Exopolysaccharide production. A pot experiment was conducted by inoculating these four isolates with blackgram crop. Four different moisture levels $(20 \%, 40 \%, 60 \%, 80 \%)$ were maintained to create stress condition. The results revealed that the pot containing combined inoculants of bacteria with ACC deaminase and EPS gives highest yield compared to control during stress condition.
\end{abstract}

\section{Introduction}

Blackgram (Vigna mungo L.) is the third important pulse crop in India. It is an annual pulse crop and native to central Asia. It is also extensively grown in West Indies, Japan and other tropics subtropical countries. Blackgram seeds are highly nutritious containing higher amount of protein (24-26\%) and are reported to be rich in potassium, phosphorus and calcium with good amount of sodium. It is also reported to be rich in vitamin A, B1, B3 besides nutritionally rich proteins, important mineral and vitamins (Selvakumar et al.,
2012). In India the area under blackgram cultivation is 3.30 million hector producing 1.60 million tones, with the mean productivity of $0.49 \mathrm{~kg} \mathrm{ha} \mathrm{ha}^{-1}$ and contributes $11 \%$ of total production in the country (Choudhary et al., 2017).

In the rhizosphere of crop plants bacteria are present abundantly. These rhizosphere bacteria are collectively called rhizobacteria. Plant growth promoting bacterial strains are rhizospheric competent which can survive and colonize the rhizosphere soil (Cattelan et al., 1999). These rhizosphere bacteria that 
positively stimulate the plant growth are called plant growth promoting rhizobacteria. The effect of rhizosphere colonization by PGPR received attention on potato plant development by Kloepper et al., (1980). They reported that inoculation of potato seed pieces with Pseudomonas fluorescence and Pseudomonas putida reduced the disease incidence and increased the yield.

Bacteria can survive under stress conditions due to the production of exopolysaccharide (EPS), which protects microorganisms from water stress by enhancing water retention and by regulating the diffusion of organic carbon sources.

EPS also help the microorganisms to irreversibly attach and colonize the roots due to involvement of a network of fibrillar material that permanently connects the bacteria to the root surface (Bashan et al., 2004).

ACC deaminase containing plant growth promoting rhizobacteria lowers the level of ACC in the stressed plants, thereby limiting the amount of stress ethylene synthesis and hence the damage to the plant. These bacteria are beneficial to plant growth as plants are often subjected to ethylene producing stress. Soil borne fluorescent pseudomonads have excellent root colonizing ability, catabolic versatility and produce a wide range of enzymes and metabolites that favour the plant withstand under varied biotic and abiotic stress conditions (Ramamoorthy et al., 2001; Vivekananthan et al., 2004 and Mayak et al., 2004). The use of PGPR containing ACC deaminase may prove useful in developing strategies to facilitate plant growth under drought conditions. Inoculation of plants with drought tolerant ACC deaminase containing native beneficial microorganisms may increase drought tolerance of plants growing in arid or semiarid areas.

\section{Materials and Methods}

For isolation of rhizobacteria, the method proposed by Vlassak et al., (1992) was followed. In this procedure $10 \mathrm{~g}$ of soil from each soil sample was taken in a conical flask with $90 \mathrm{ml}$ water. The sample was agitated for 15 minutes on a vortex and serial dilution of soil suspension was prepared. Dilution prepared and used for different bacteria are given below.

For Rhizobium sp. $-10^{-3}$ to $10^{-5}$

For Pseudomonas sp. $-10^{-3}$ to $10^{-5}$

For K releasing bacteria $-10^{-2}$ to $10^{-4}$

For $\mathrm{Zn}$ solubilizing bacteria $-10^{-2}$ to $10^{-4}$

$0.1 \mathrm{ml}$ of respective dilutions were spread on specific sterilized solid media i.e., Yeast extract mannital agar for Rhizobium, Pikovskaya's medium for Pseudomonas, Modified Aleksandrov medium containing 0.2 $\%$ insoluble mica powder or potassium alumino silicate as insoluble potassium source for $\mathrm{K}$ releasing bacteria, Mineral salts agar medium was amended with $0.1 \%$ of either insoluble zinc oxide $(\mathrm{ZnO})$ or zinc phosphate for Zinc solubilizing bacteria contained in sterile petri plates and the petri plates were incubated at room temperatures $\left(28^{0} \mathrm{C} \pm 2^{0} \mathrm{C}\right)$ for 24-72 h.

\section{Screening for ACC deaminase activity}

Screening for ACC deaminase activity of drought tolerant PGPR isolates was done based on their ability to use ACC as a sole nitrogen source. All the nine drought tolerant PGPR isolates were grown in $5 \mathrm{ml}$ of Trypticase Soya Broth (TSB) medium incubated at $28^{0} \mathrm{C}$ at $120 \mathrm{rpm}$ for $24 \mathrm{~h}$. The cells were harvested by centrifugation at 3000 $g$ for 5 minutes and washed twice with sterile $0.1 \mathrm{M}$ Tris- $\mathrm{HCl}(\mathrm{pH} 7.5)$ and resuspended in 1 $\mathrm{ml}$ of $0.1 \mathrm{M}$ Tris- $\mathrm{HCl}(\mathrm{pH}$ 7.5) and spot inoculated on petri plates containing modified 
DF (Dworkin and Foster) salts minimal medium $10 \mathrm{ml}$ and distill water $990 \mathrm{ml}$, supplemented with $3 \mathrm{mM}$ ACC as sole nitrogen source. Plates containing only DF salts minimal medium without $\mathrm{ACC}$ as negative control and with $(\mathrm{NH} 4)_{2} \mathrm{SO}_{4}(0.2 \%$ $\mathrm{w} / \mathrm{v})$ as positive control. The plates were incubated at $28^{0} \mathrm{C}$ for $72 \mathrm{~h}$. Growth of isolates on ACC supplemented plates was compared to negative and positive controls and was selected based on growth by utilizing ACC as nitrogen source (Honma and Shimomura, 1978).

\section{EPS production}

Bacterial strains grown on YMG agar medium were inoculated in YMG broth and preincubated at $25^{\circ} \mathrm{C}$ for 24 h. $200 \mu$ l of culture broth was inoculated into $50 \mathrm{ml}$ of YMG broth and incubated at $25^{\circ} \mathrm{C}$ for 5 days at $120 \mathrm{rpm}$. Elimination of cells was followed by centrifugation (10,000`g for $20 \mathrm{~min})$.

The culture broth was mixed with 3 volumes of ethanol and after standing at $4^{0} \mathrm{C}$ for $24 \mathrm{~h}$, it was centrifuged $\left(10,000^{\prime} \mathrm{g}, 4^{0} \mathrm{C}, 20 \mathrm{~min}\right)$. The weight of the precipitated EPS was measured after drying at $80^{\circ} \mathrm{C}$ for 3 days (Ashok et al., 2011).

Details of the treatments used in the pot experiment

Location: ARS, Amaravathi

Season: Rabi - 2016

Crop: Blackgram

Design: CRD (pot culture)

Treatments: 9

Replications: 3

\section{Treatments}

$\mathrm{T}_{1}$ - Control

$\mathrm{T}_{2}-20 \% \mathrm{WHC}+\mathrm{NF}+\mathrm{PSB}+\mathrm{KRB}$
$\mathrm{T}_{3}-40 \% \mathrm{WHC}+\mathrm{NF}+\mathrm{PSB}+\mathrm{KRB}$

$\mathrm{T}_{4}-60 \% \mathrm{WHC}+\mathrm{NF}+\mathrm{PSB}+\mathrm{KRB}$

$\mathrm{T}_{5}-80 \% \mathrm{WHC}+\mathrm{NF}+\mathrm{PSB}+\mathrm{KRB}$

$\mathrm{T}_{6}-20 \% \mathrm{WHC}+\mathrm{NF}+\mathrm{PSB}+\mathrm{KRB}+\mathrm{ZN}$

Solubilizer + Antagonistic PGPR

$\mathrm{T}_{7}-40 \% \mathrm{WHC}+\mathrm{NF}+\mathrm{PSB}+\mathrm{KRB}+\mathrm{ZN}$

Solubilizer + Antagonistic PGPR

$\mathrm{T}_{8}-60 \% \mathrm{WHC}+\mathrm{NF}+\mathrm{PSB}+\mathrm{KRB}+\mathrm{ZN}$

Solubilizer + Antagonistic PGPR

$\mathrm{T}_{9}-80 \% \mathrm{WHC}+\mathrm{NF}+\mathrm{PSB}+\mathrm{KRB}+\mathrm{ZN}$

Solubilizer + Antagonistic PGPR

WHC: Water holding capacity

NF: Nitrogen fixer

PSB: Phosphate solubilizing bacteria

KRB: Potassium releasing bacteria

\section{Water management}

The experiment was performed in pots containing soil at different water levels (i.e., $80 \% \mathrm{WHC}, 60 \% \mathrm{WHC}, 40 \% \mathrm{WHC}$ and $20 \%$ WHC). Water level in each treatment was maintained by adding water daily on weight loss basis.

$20 \%, 40 \%, 60 \%$ and $80 \%$ water holding capacity were maintained in different pots according to treatment wise.

\section{Water holding capacity}

Per cent of water holding capacity of the soil samples were determined with the help of Keen-Raczkowski box (Piper, 1967). A soil sample was allowed to soak water for $24 \mathrm{~h}$. The saturated soil sample was kept in previously weighed Keen box and weighed. Then it was allowed to dry for $24 \mathrm{~h}$ in an oven at $105^{\circ} \mathrm{C}$. The weight of the oven dried soil 
samples with the box was taken. The water holding capacity of soil samples were calculated as follows:

Water holding capacity of the soil $=\frac{b-c}{c-a} \times 100$

Where,

$\mathrm{a}=$ weight of the Keen box

$b=$ weight of the Keen box (a) + saturated soil

$c=$ weight of the Keen box (a) + dried soil

\section{Plant height (cm)}

The plant height was recorded by measuring the total height from the base of the plant to the tip of the plant flowering and harvesting stages.

\section{Number of leaves per plant}

The number of leaves per plant present in each plant at selected stages were counted and recorded.

\section{Number of branches per plant}

The number of branches per plant present in each plant at selected stages were counted and recorded.

\section{Number of pods per plant}

The number of pods per plant present in each plant were counted and recorded.

\section{Number of seeds per pod}

The number of seeds pod $^{-1}$ was recorded by counting the number of seeds in each pod

\section{Test weight (100 seed weight) (g)}

Five samples each of 100 seeds were collected randomly from the net plot produce treatment wise and weighed, averaged and expressed in grams.

\section{Seed yield $\left(\mathrm{g} \mathrm{pot}^{-1}\right)$}

The weight of the seeds per pot was taken by using weighing balance.

\section{Results and Discussion}

Rhizosphere soil samples from blackgram plants were collected and used for the isolation of PGPR using specific media. The attempts yielded 32 bacterial isolates. All 32 isolates were tested for their ACC deaminase activity and EPS production. Among them 4 isolates were exhibited highest amount of ACC deaminase activity and EPS production. These 4 isolates were used for pot culture experiment.

\section{ACC deaminase activity of different PGPR isolates}

All PGPR isolates were screened for ACC deaminase based on the enrichment method, where ACC was used as the sole nitrogen source. The data on ACC deaminase activity of all PGPR isolates were shown in Table 1. Among 32 PGPR isolates, four isolates i.e., KUR1, KCP1, KGK1, STZ1 grew well (+++) on DF salt minimal medium with either ACC or ammonium sulfate serving as the sole nitrogen source which was compared with DF salt minimal medium without nitrogen source.

Similar results were observed with Ali et al., (2014) screened nine drought tolerant isolates for ACC deaminase based on the enrichment method, where ACC was used as the sole nitrogen source. Among nine isolates, one isolates (SorgP4) grew well on DF salt minimal medium with either ACC or ammonium sulfate serving as the sole nitrogen source which was compared with DF salt minimal medium without nitrogen source. 
Isolate SorgP4 which was positive for ACC deaminase under drought stress condition.

Zahir et al., (2008) concluded that the rhizobacteria having ACC deaminase activity are effective in promoting plant growth and water use efficiency under drought conditions, by lowering the ethylene whose higher levels have inhibitory effects on root and shoot growth.
Exopolysaccharide (EPS) Production by Different PGPR Isolates

Exopolysaccharide was produced by all PGPR isolates. The data on EPS production of all PGPR isolates were shown in Table 2. Among 32 PGPR isolates maximum amount of EPS production was observed in four isolate i.e., KUR1 (34.6 mg ml${ }^{-1}$ ), KCP1 (30.6 $\mathrm{mg} \mathrm{ml}^{-1}$ ), KGK1 $\left(20.3 \mathrm{mg} \mathrm{ml}^{-1}\right)$, STZ1 $\left(24.6 \mathrm{mg} \mathrm{ml}^{-1}\right)$.

Table.1 ACC deaminase activity of different PGPR isolates

\begin{tabular}{|c|l|c|c|c|c|c|c|c|c|} 
S.No. & \multicolumn{2}{|c|}{ Rhizobium } & \multicolumn{2}{|c|}{ Pseudomonas } & \multicolumn{2}{|c|}{ KRB } & \multicolumn{2}{|c|}{ ZSB } \\
\hline & $\begin{array}{c}\text { Isolate } \\
\text { name }\end{array}$ & $\begin{array}{c}\text { ACC } \\
\text { deaminase } \\
\text { activity }\end{array}$ & $\begin{array}{c}\text { Isolate } \\
\text { name }\end{array}$ & $\begin{array}{c}\text { ACC } \\
\text { deaminase } \\
\text { activity }\end{array}$ & $\begin{array}{c}\text { Isolate } \\
\text { name }\end{array}$ & $\begin{array}{c}\text { ACC } \\
\text { deaminase } \\
\text { activity }\end{array}$ & $\begin{array}{c}\text { Isolate } \\
\text { name }\end{array}$ & $\begin{array}{c}\text { ACC } \\
\text { deaminase } \\
\text { activity }\end{array}$ \\
\hline $\mathbf{1}$ & KCR1 & + & KCP1 & +++ & KCK1 & ++ & KCZ1 & ++ \\
\hline $\mathbf{2}$ & KGR1 & ++ & KGP1 & ++ & KGK1 & +++ & KGZ1 & ++ \\
\hline $\mathbf{3}$ & KUR1 & +++ & KUP1 & ++ & KUK1 & ++ & KUZ1 & ++ \\
\hline $\mathbf{4}$ & VKR1 & ++ & VKP1 & + & VKK1 & - & VKZ1 & + \\
\hline $\mathbf{5}$ & SCR1 & ++ & SCP1 & ++ & SCK1 & +++ & SCZ1 & - \\
\hline $\mathbf{6}$ & STR1 & - & STP1 & ++ & STK1 & + & STZ1 & +++ \\
\hline 7 & BRR1 & ++ & BRP1 & + & BRK1 & - & BRZ1 & ++ \\
\hline $\mathbf{8}$ & BVR1 & + & BVP1 & + & BVK1 & ++ & BVZ1 & + \\
\hline
\end{tabular}

Table.2 Exopolysaccharide (EPS) production by different PGPR isolates

\begin{tabular}{|c|c|c|c|c|c|c|c|c|}
\hline \multirow[t]{2}{*}{ S.No. } & \multicolumn{2}{|c|}{ Rhizobium } & \multicolumn{2}{|c|}{ Pseudomonas } & \multicolumn{2}{|c|}{ KRB } & \multicolumn{2}{|c|}{ ZSB } \\
\hline & $\begin{array}{c}\text { Isolate } \\
\text { name }\end{array}$ & $\begin{array}{c}\text { EPS } \\
\left(\mathrm{mg} \mathrm{ml}^{-1}\right)\end{array}$ & $\begin{array}{c}\text { Isolate } \\
\text { name }\end{array}$ & $\begin{array}{c}\text { EPS } \\
\left(\mathrm{mg} \mathrm{ml}^{-1}\right)\end{array}$ & $\begin{array}{c}\text { Isolate } \\
\text { name }\end{array}$ & $\begin{array}{c}\text { EPS } \\
\left(\mathrm{mg} \mathrm{ml}^{-1}\right)\end{array}$ & $\begin{array}{c}\text { Isolate } \\
\text { name }\end{array}$ & $\begin{array}{c}\text { EPS } \\
\left(\mathrm{mg} \mathrm{ml}^{-1}\right)\end{array}$ \\
\hline 1 & KCR1 & 26.6 & $\mathrm{KCP} 1$ & 30.6 & KCK1 & 13.0 & $\mathrm{KCZ1}$ & 22.3 \\
\hline 2 & KGR1 & 27.6 & KGP1 & 17.6 & KGK1 & 20.3 & KGZ1 & 22.6 \\
\hline 3 & KUR1 & 34.6 & KUP1 & 22.6 & KUK1 & 14.3 & KUZ1 & 23.3 \\
\hline 4 & VKR1 & 14.6 & VKP1 & 25.3 & VKK1 & 10.6 & VKZ1 & 15.3 \\
\hline 5 & SCR1 & 12.6 & SCP1 & 24.3 & SCK1 & 16.6 & SCZ1 & 19.6 \\
\hline 6 & STR1 & 32.6 & STP1 & 21.3 & STK1 & 19.3 & STZ1 & 24.6 \\
\hline 7 & BRR1 & 24.6 & BRP1 & 13.6 & BRK1 & 10.3 & BRZ1 & 21.6 \\
\hline 8 & BVR1 & 27.3 & BVP1 & 23.3 & BVK1 & 17.6 & BVZ1 & 18.6 \\
\hline
\end{tabular}


Table.3 Influence of stress tolerant plant growth promoting rhizobacteria on yield attributing characters and yield of blackgram

\begin{tabular}{|c|c|c|c|c|c|c|c|}
\hline Treatments & Plant ht & $\begin{array}{c}\text { No. of } \\
\text { branches/ } \\
\text { plant }\end{array}$ & $\begin{array}{c}\text { No. of } \\
\text { leaves/plant }\end{array}$ & $\begin{array}{c}\text { No. of } \\
\text { pods } \\
\text { plant }^{-1}\end{array}$ & $\begin{array}{c}\text { No. of } \\
\text { seeds pod }\end{array}$ & $\begin{array}{c}\text { Seed } \\
\text { yield } \\
\text { (kg ha }\end{array}$ & $\begin{array}{c}\mathbf{1 0 0} \text { seed } \\
\text { weight } \\
\text { (gm) }\end{array}$ \\
\hline $\mathrm{T}_{1}$ & 32.3 & 10.20 & 32.3 & 18.3 & 3.0 & 1645.0 & 3.16 \\
\hline $\mathrm{T}_{2}$ & 32.6 & 10.30 & 32.6 & 21.3 & 3.3 & 1890.0 & 3.56 \\
\hline $\mathrm{T}_{3}$ & 34.6 & 11.20 & 34.6 & 23.7 & 4.0 & 2165.0 & 4.24 \\
\hline $\mathrm{T}_{4}$ & 35.3 & 11.30 & 35.3 & 27.7 & 4.6 & 2375.0 & 4.34 \\
\hline $\mathrm{T}_{5}$ & 36.6 & 11.33 & 36.6 & 31.7 & 5.0 & 2703.0 & 4.72 \\
\hline $\mathrm{T}_{6}$ & 33.6 & 10.60 & 33.6 & 22.3 & 3.9 & 2005.0 & 4.21 \\
\hline $\mathrm{T}_{7}$ & 35.0 & 11.26 & 35.0 & 25.7 & 4.3 & 2245.0 & 4.30 \\
\hline $\mathrm{T}_{8}$ & 35.6 & 11.32 & 35.6 & 29.3 & 4.9 & 2462.0 & 4.45 \\
\hline $\mathrm{T}_{9}$ & 39.0 & 11.60 & 39.0 & 32.3 & 5.0 & 2815.0 & 4.98 \\
\hline
\end{tabular}

Plate.1 Pot culture study of stress tolerant plant growth promoting rhizobacteria with blackgram
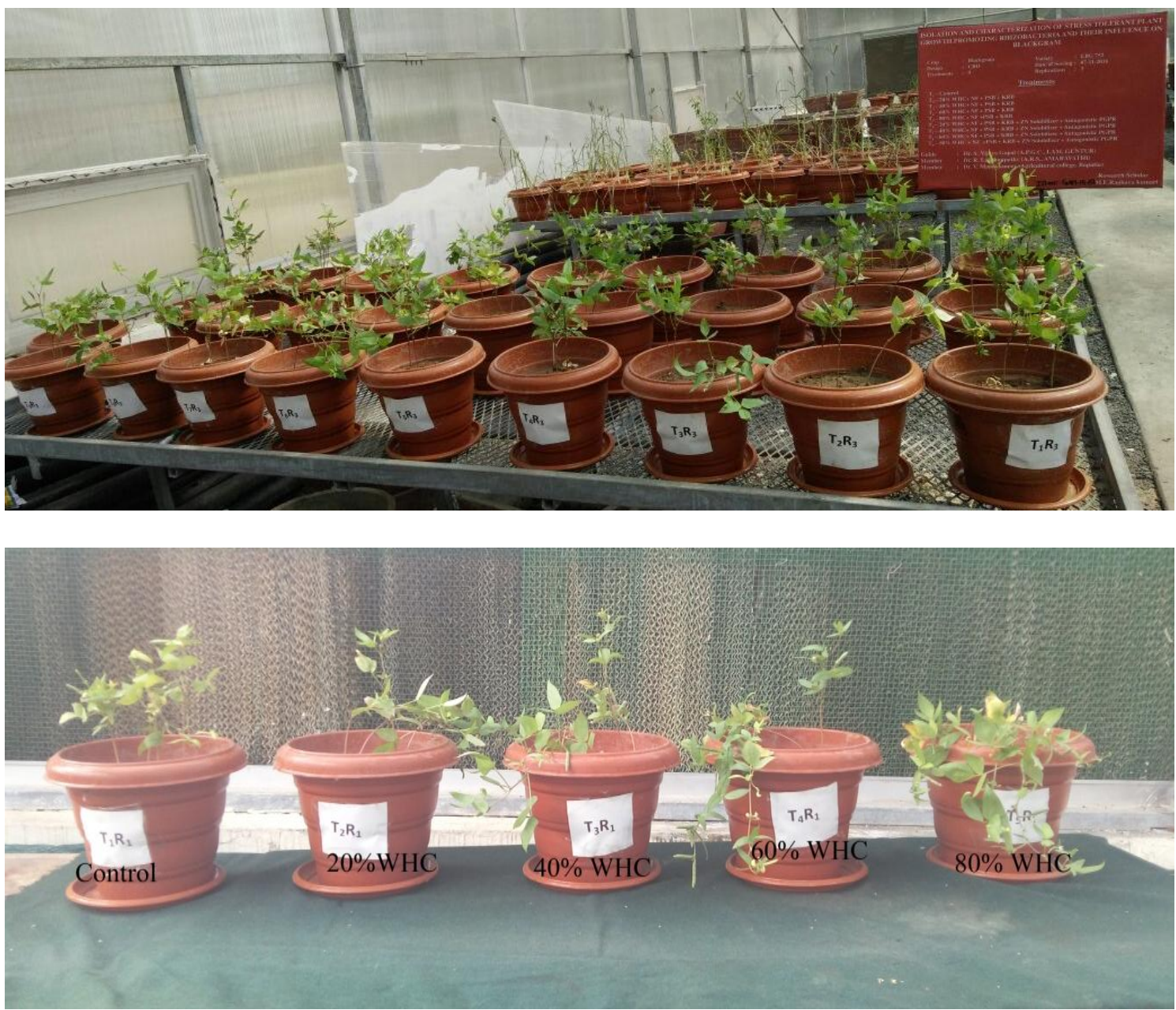


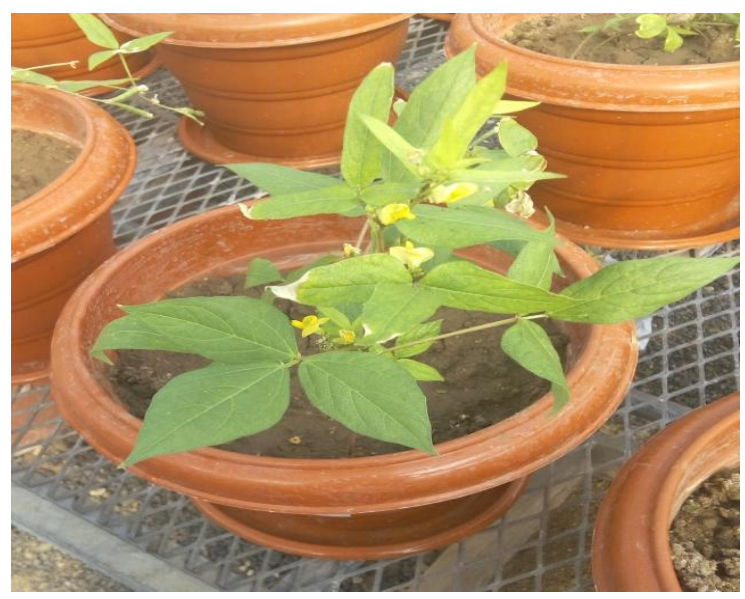

Similar results were observed by Borgio et al., (2009) reported three bacterial strains, Bacillus subtilis NCIM 2063, Pseudomonas aeruginosa NCIM 2862 and Streptococcus mutans MTCC 1943 were examined for their exopolysaccharide (EPS) producing ability at the laboratory level. The highest EPS production was recorded in Pseudomonas aeruginosa $\left(226 \mu \mathrm{g} \mathrm{ml}^{-1}\right)$ grown in nitrogen free medium followed by Streptococcus mutans and Bacillus subtilis (220 and $206 \mu \mathrm{g}$ $\mathrm{ml}^{-1}$ respectively) in nitrogen free medium after 7 days of incubation at $37^{\circ} \mathrm{C}$.

Modi et al., (1989) carried their research work on extracellular polysaccharides of Cowpea Rhizobium. They concluded that maximum amount of EPS production was observed in isolate MS3 (33.6 mg ml$)^{-1}$ ) followed by MS1 $\left(28 \mathrm{mg} \mathrm{ml}^{-1}\right)$, MS4 $\left(27 \mathrm{mg} \mathrm{ml}^{-1}\right)$, MS2 $(23 \mathrm{mg}$ $\left.\mathrm{ml}^{-1}\right)$ and MS5 $\left(12 \mathrm{mg} \mathrm{ml}^{-1}\right)$ after five days of incubation.

Influence of stress tolerant PGPR on growth parameters of blackgram

Plant height at 30 DAS was found significantly highest in $\mathrm{T}_{9}(80 \% \mathrm{WHC}+\mathrm{NF}$ $+\mathrm{PSB}+\mathrm{KRB}+\mathrm{Zn}$ Solubilizer + Antagonistic PGPR) $39.0 \mathrm{~cm}$ compared to $\mathrm{T}_{1}$ (Control) i.e., $32.3 \mathrm{~cm}$. Number of branches and leaves per plant at 75 DAS was found significantly highest in $\mathrm{T}_{9}(80 \% \mathrm{WHC}+\mathrm{NF}+\mathrm{PSB}+\mathrm{KRB}$

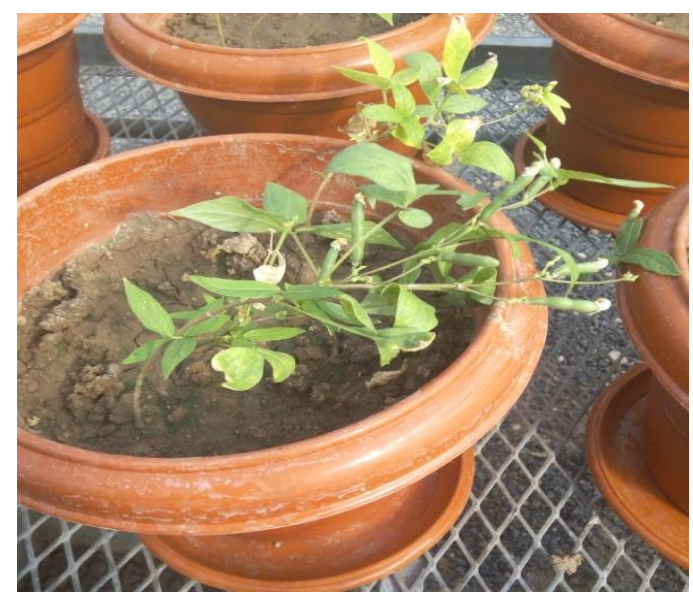

$+\mathrm{Zn}$ Solubilizer + Antagonistic PGPR) i.e., 11.60 and 39.0 respectively compared to $T_{1}$ (Control) i.e., 10.20 and 32.3 respectively. Number of pods per plant, Number of seeds per pod, seed yield, Weight of 100 seeds were found highest in $\mathrm{T}_{9}(80 \% \mathrm{WHC}+\mathrm{NF}+\mathrm{PSB}$ $+\mathrm{KRB}+\mathrm{Zn}$ Solubilizer + Antagonistic PGPR) i.e., $32.3,5,2815.0 \mathrm{~kg} \mathrm{ha}^{-1}, 4.98 \mathrm{~g}$ respectively compared to control (Table 3 ).

Similar results were observed with Maheswari et al., (2014) carried their research work on effectiveness of the growth of Vigna mungo using liquid biofertilizers. They concluded that Utilization of liquid biofertilizer in combined inoculation of treatments such as Rhizobium + Azospirillum + Azotobacter $\left(\mathrm{T}_{7}\right)$ in $60^{\text {th }}$ day was the best response $(31.6 \pm 1.52$ $\mathrm{cm})$ followed by other treatments and control. Amruta et al., (2015) concluded that that fertilizer application@ 50:100:100 NPK kg $\mathrm{ha}^{-1}+$ blackgram Rhizobia $\left(250 \mathrm{~g} \mathrm{ha}^{-1}\right)+$ PSBBacillus megaterium $\left(250 \mathrm{~g} \mathrm{ha}^{-1}\right)$ with the spacing of $60 \times 10 \mathrm{~cm}$ recorded significantly higher number of branches plant ${ }^{-1}$ (5.60), number of leaves plant ${ }^{-1}(29.87)$.

Similar results were observed with Rajesh $e t$ al., (2013). They concluded that the highest yield parameters like number of pods per plant, number of seeds and weight of 100 seeds were recorded in the greengram crop grown under the combined application of 
biofertilizers (Rhizobium leguminosorum, Bacillus megaterium and Bacillus mucilaginosus) when compared with control as well as other treatments. Dorle et al., (2015) concluded that significantly higher mean seed yield was recorded in blackgram with the application of RDF + Rhizobium (LB) + PSB (LB) than rest of the treatments.

In the present study pot experiment was conducted by inoculating stress tolerant PGPR isolates with blackgram crop with different moisture levels and concluded that plant height, number of branches and leaves per plant, number of pods plant ${ }^{-1}$, number of seeds $\operatorname{pod}^{-1}$, seed yield, 100 seed weight was found highest in $\mathrm{T}_{9}(80 \% \mathrm{WHC}+\mathrm{NF}+\mathrm{PSB}+$ $\mathrm{KRB}+\mathrm{Zn}$ Solubilizer + Antagonistic PGPR). It is indicated that the combined application of PGPR containing highest ACC deaminase activity and EPS increases yield of blackgram compared to control by decreasing moisture stress in the plants.

\section{References}

Ali, S.Z., Sandhya, V and Rao, V.V. 2014. Isolation and characterization of drought-tolerant ACC deaminase and exopolysaccharide producing fluorescent Pseudomonas sp. Annals of Microbiology. 64: 493-502.

Amruta, N., Maruthi, J.B., Sarika, G and Deepika, C. 2015. Effect of integrated nutrient management and spacing on growth and yield parameters of blackgram cv. LBG-625 (RASHMI). An International Quarterly Journal of Life Sciences. 10(1): 193-198.

Ashok, K.M., Anandapandian, K.T.K and Parthiban, K. 2011. Production and characterization of exopolysaccharides (EPS) from biofilm forming marine bacterium. Brazilian Archives of Biology and Technology. 54(2): 259265.
Bashan, Y., Holguin, $\mathrm{G}$ and Bashan, L.E 2004. Azospirillum plant relationship: physiological, molecular, agricultural and environmental advances. Canadian Journal of Microbiology. 50(8): 521577.

Borgio, F.J., Bency, B.J., Ramesh, S and Amuthan, M. 2009. Exopolysaccharide production by Bacillus subtilis NCIM 2063, Pseudomonas aeruginosa NCIM 2862 and Streptococcus mutans MTCC 1943 using batch culture in different media. African Journal of Biotechnology. 9(20): 5454-5457.

Cattelan, A.J., Hartel, P.G and Fuhrmann, J.J. 1999. Screening of plant growth promoting rhizobacteria to promote early soybean growth. Soil Science Society of America Journal. 63: 16701680.

Choudhary, P., Singh, G., Lakshma Reddy, G and Bhanwar L.J. 2017. Effect of biofertilizer on different varieties of blackgram (Vigna mungo L). International Journal of Current Microbiology and Applied Sciences. 6(2): 302-316.

Dorle, V.R., Awasarmal, V.B., Mirza I.A.B and Pawar, S.U. 2015. Effect of carrier and liquid based Rhizobium and PSB on growth and yield of blackgram (Vigna mungo L.). International Journal of Tropical Agriculture. 33(4): 2641-2643.

Honma, $M$ and Shimomura, T. 1978. Metabolism of 1-Aminocyclopropane1-carboxylic acid. Agricultural and Biological Chemistry. 42: 1825-1831.

Kloepper, J.W., Schroth, M.N and Miller, T.D. 1980. Effects of rhizosphere colonization by plant growth promoting rhizobacteria on potato plant development and yield. Phyto Pathology. 70: 1078-1082.

Maheswari, N.U and Elakkiya, T. 2014. Effect of liquid biofertilizers on growth and yield of vigna mungo $\mathrm{L}$. 
International Journal of Pharmaceutical Sciences Review and Research. 29(2): $42-45$

Mayak, S. 2004. Plant growth promoting bacteria that confer resistant to water stress in tomato and pepper. Plant science. 166(2): 525-530.

Mody, B., Bindra, M and Modi, V. 1989. Extracellular polysaccharides of cowpea Rhizobia: compositional and functional studies. Archives of Microbiology. 153(1): 38-42.

Piper, C.S. 1967. Soil and Plant analysis. Hans Publishers, Bombay.

Rajesh, M., Jayakumar, K and Kannan, S.T.M. 2013.Effect of biofertilizers application on growth and yield parameters of green gram (Vigna radiata). International Journal of Environment and Bioenergy. 7(1): 4353.

Ramamoorthy, V., Viswanathan, R., Raghuchander, T., Prakasam, V and Samiyappan, R. 2001. Induction of systemic resistance by plant growth promoting rhizobacteria in crop plants against pests and diseases. Crop Protection. 20(1): 1-11.

Selvakumar, G., Reetha, S and
Thamizhiniyan, P. 2012. Response of biofertilizers on growth, yield attributes and associated protein profiling changes of blackgram (Vigna mungo L. Hepper). World Applied Sciences Journal. 16(10): 1368-1374.

Vivekananthan, R., Ravi, M., Ramanathan, A and Samiyappan, R. 2004. Lytic enzymes induced by pseudomonas fluorescens and other biocontrol organisms mediate defence against the anthracnose pathogen in mango. World Journal of Microbiology \& Biotechnology. 20: 235-244.

Vlassak, K.L., Van, H and Duchateau, L. 1992. Isolation and characterization of fluorescent Pseudomonas associated with the roots of rice and banana grown in Srilanka. Plant and soil. 145: 51-63.

Zahir, Z.A., Munir, A., Asghar, N., Shaharoona, B and Arshad, M.2008. Effectiveness of rhizobacteria containing ACC deaminase for growth promotion of peas (Pisum sativum) under drought conditions. Journal of Microbiology and Biotechnology. 18(5): 958-963.

\section{How to cite this article:}

Eswara Raghava Kumari, M., A. Vijaya Gopal and Lakshmipathy, R. 2018. Effect of Stress Tolerant Plant Growth Promoting Rhizobacteria on Growth of Blackgram under Stress Condition. Int.J.Curr.Microbiol.App.Sci. 7(01): 1479-1487.

doi: https://doi.org/10.20546/ijcmas.2018.701.180 